\title{
Preparation and Characterization of Pseudopoly(trans-4-hydroxy-L-proline ester) ${ }^{\dagger}$
}

\author{
Ren-Shen LeE, ${ }^{\dagger \dagger}$ Jen-Ming YANG, ${ }^{*}$ and Kai-Hung HUANG* \\ Center of General Education, Chang Gung University, \\ Taoyuan, Taiwan, Republic of China \\ * Department of Chemical Engineering, Chang Gung University, \\ Taoyuan, 333, Taiwan, Republic of China
}

(Received September 16, 1998)

\begin{abstract}
The preparation and characterization of polyesters derived from hydroxyproline were investigated. Two new polymers of poly(trans-4-hydroxy- $N$-benzyloxycarbonyl-L-proline) $[\mathrm{poly}(N-Z-\mathrm{Hpr}-\mathrm{OH})]$ and poly $($ trans-4-hydroxy- $N$ benzyloxycarbonyl-L-proline ester) [poly $(N-Z$-Hpr-OMe)], with easily removable pendant $N$-benzyloxycarbonyl group, were prepared. Weight-average molecular weight $\left(M_{w}\right)$ of about 254000 and 33000 were obtained via esterification or transesterification, using stannous octoate as a catalyst, at $140^{\circ} \mathrm{C}$ under vacuum $(20 \mathrm{mmHg})$ for $16 \mathrm{~h}$. Removal of the $N$-benzyloxycarbonyl group by catalytic transfer hydrogenation yielded pseudopoly $($ trans-4-hydroxy-L-proline ester) [poly $(\mathrm{Hpr}-\mathrm{OMe} \cdot \mathrm{HCl})$ ].

KEY WORDS Pseudopoly(amino acid)s / Hydroxyproline / Homopolymer /
\end{abstract}

Over the past decade the use of biodegradable polymeric materials for a variety of medical applications (drug delivery, sutures, temporary vascular grafts, or orthopedic implants) has increased dramatically. ${ }^{1}$

Pseudopoly(amino acid)s are one of the newest classes of biodegradable polymers being different from conventional poly(amino acid)s in that the polymer backbone is formed by utilizing the side-chain functional groups on the monomeric $\alpha$-L-amino acids or dipeptides. Such an approach offers the opportunity to create polymers from naturally occurring metabolites but without some of the potential disadvantages of conventional poly(amino acid)s resulting from the repeating amide bonds (e.g., poor mechanical strength and enzymatic degradation). ${ }^{2}$

To date, only some types of those homopolymers have been reported in the literature. For example, Kohn et $a l .{ }^{3}$ synthesized the pseudopoly(L-serine ester)s from the $N$-benzyloxycarbonyl-L-serine- $\beta$-lactones that were not readily available. Langer et al. ${ }^{4}$ described the synthesis of pseudopoly(trans-4-hydroxy- $N$-acyl-L-proline ester)s from methyl trans-4-hydroxy- $N$-acyl-L-proline esters from which the $N$-acyl protecting group cannot be easily removed. Therefore, the poly(trans-4-hydroxy-L-proline ester) cannot be prepared with free amino pendant group.

In order to develop biodegradable polymers whose pendant groups can be chemically modified or used as sites for covalent attachment of drugs or bioactive molecules, we have studied the synthesis of poly(trans4-hydroxy- $N$-benzyloxycarbonyl-L-proline) [poly $(N-Z$ $\mathrm{Hpr}-\mathrm{OH})] 3$ and poly(trans-4-hydroxy- $N$-benzyloxycarbonyl-L-proline methyl ester) [poly $(N-Z-H p r-O M e)] 6$ from trans-4-hydroxy-L-proline 1 by esterification or transesterification (Scheme 1). These new polymers were identified by ${ }^{1} \mathrm{H}$ NMR, IR, GPC, and their thermal properties were also examined.

\section{EXPERIMENTAL}

\section{Materials}

trans-4-Hydroxy-L-proline, benzyloxychloroformate, thionyl chloride, formic acid, and Palladium $(10 \%)$ on activated carbon were purchased from Aldrich Chemical Co. Stannous octoate was purchased from Strem Chemical Co. Organic solvent (e.g., tetrahydrofuran, methanol, $N, N^{\prime}$-dimethylformamide, and ethylacetate) were HPLC grade and inorganic compounds (e.g., sodium sulfate, sodium bicarbonate) were reagent grade.

\section{Characterization}

Melting point determinations were made on a Buchi 535 melting point apparatus. Infrared spectra were measured on a JASCO IR Report-100 infrared spectrophotometer. Samples were either neat onto $\mathrm{NaCl}$ plates or pressed into $\mathrm{KBr}$ pellets. ${ }^{1} \mathrm{H}$ NMR spectra were recorded at $60 \mathrm{MHz}$ (Varian EM 360L) or $500 \mathrm{MHz}$

(A).

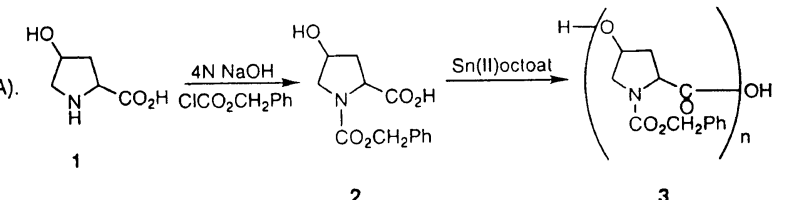

(B)
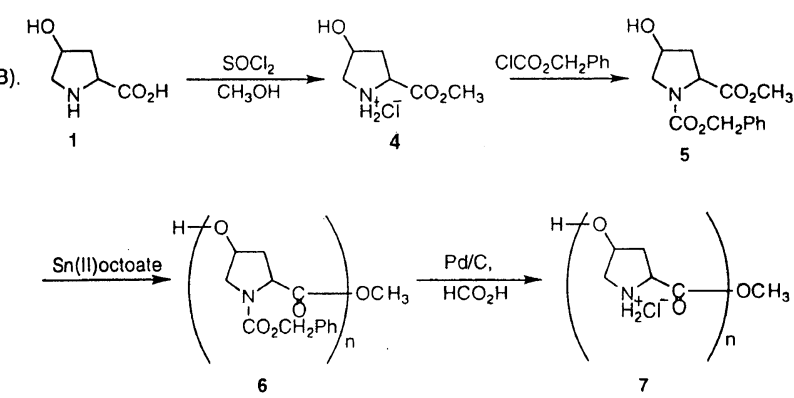

Scheme 1. The synthesis of $\operatorname{poly}(N-Z-H p r-O H) 3$, and poly $(\mathrm{Hpr}$ $\mathrm{OMe} \cdot \mathrm{HCl}) 7$.

\footnotetext{
${ }^{\dagger}$ Abstract published in the 21st ROC Polymer Symposium (Taipei), June 25, 26, 1998.

${ }_{\dagger}$ To whom correspondence should be addressed at Center of General Education, Chang Gung University, Taoyuan 333, Taiwan, Republic of China.
} 
(Brucker WB/DMX-500 spectrometer), using tetramethylsilane as an internal standard. The weight- and number-average molecular weights $\left(M_{w}\right.$ and $M_{n}$, respectively) of polymer samples dissolved in tetrahydrofuran were determined by a gel-permeation chromatography (GPC) system consisting of a PerkinElmer Series 410 LC pump, a Waters Model 410 RI detector, and a Perkin-Elmer 3600 data station. A PL gel, $5 \mu \mathrm{m}$, mixed column (Polymer Laboratories) was used. The flow rate was $0.9 \mathrm{ml} \mathrm{min}{ }^{-1}$. The Perkin-Elmer CHROM 2 program was used to run the samples, and the GPC4 program was used to calculate the average molecular weight of the polymer relative to polystyrene standards (Polysciences, $580-160000 \mathrm{~g} \mathrm{~mol}^{-1}$ ). Elemental analysis was performed on a Perkin-Elmer $240 \mathrm{C}$, 2400.EA. Thermal analysis of the polymer was performed on a Du Pont 9900 system that consists of a DSC differential scanning calorimeter.

\section{Synthesis of Monomers}

trans-4-Hydroxy-N-benzyloxycarbonyl-L-proline $(N-Z$ $\mathrm{Hpr}-\mathrm{OH}$ ) 2. A solution of trans-4-hydroxy-L-proline $1(2.62 \mathrm{~g}, 0.02 \mathrm{~mol})$ in $2 \mathrm{~N} \mathrm{NaOH}(10 \mathrm{ml})$ was cooled in an ice-water bath and stirred with a powerful magnetic stirrer. Benzylchloroformate $(3.16 \mathrm{ml})$ and $2 \mathrm{~N} \mathrm{NaOH}$ $(11 \mathrm{ml})$ were added in about ten portions, alternatingly. The reaction of mixture should remain distinctly alkaline. If necessary more $2 \mathrm{~N} \mathrm{NaOH}$ is added. The temperature of the reaction mixture was kept between 5 and $10^{\circ} \mathrm{C}$ by the rate of addition of the reactants. Then the ice-water bath was replaced by water of room temperature, and vigorous stirring was continued for $30 \mathrm{~min}$. The alkaline solution was extracted four times with ether $(10 \mathrm{ml}$ each). The ether extracted was discarded. The aqueous layer was acidified to Congo Blue by the addition of $5 N \mathrm{HCl}$, and the aqueous solution was extracted with ethyl acetate $(20 \mathrm{ml} \times 3)$. The combined organic layers were dried over $\mathrm{Na}_{2} \mathrm{SO}_{4}$ and evaporated to dryness under reduced pressure. A colorless oil product 2 was given, yield 56\%: IR (neat) 3400, 2945, 1725, 1680, 1420, 1120, 765, $698 \mathrm{~cm}^{-1} ;{ }^{1} \mathrm{H} \quad \mathrm{NMR} \quad\left(\mathrm{CDCl}_{3} /\right.$ dimethyl sulfoxide (DMSO)- $\left.d_{6}\right) \delta 7.26-7.22(\mathrm{~m}, 5), 5.13(\mathrm{dd}, 1, J=12.7$, $3.3 \mathrm{~Hz}), 5.08(\mathrm{dd}, 1, J=12.7,5.1 \mathrm{~Hz}), 4.73-4.40(\mathrm{~m}, 2)$, $3.62-3.60(\mathrm{~m}, 2), 3.23(\mathrm{~d}, 1, J=11.5 \mathrm{~Hz}), 2.20-2.01(\mathrm{~m}$, 1), $2.00-1.97(\mathrm{~m}, 1) \mathrm{ppm}$; MS $m / z$ (relative intensity) $265\left(\mathrm{M}^{+}, 5\right), 130$ (50), 91 (100). Anal. Calcd for $\mathrm{C}_{13} \mathrm{H}_{15} \mathrm{NO}_{5}$ : C, $58.86 \%$; H, 5.70\%; N, 5.28\%. Found: C, $58.09 \%$; H, $5.87 \%$; N, $5.06 \%$.

trans-4-Hydroxy-L-proline Methyl Ester Hydrochloride $(\mathrm{Hpr}-\mathrm{OMe} \cdot \mathrm{HCl})$ 4. By a thionyl chloride technique, trans-4-hydroxy-L-proline methyl ester hydrochloride $(\mathrm{Hpr}-\mathrm{OMe} \cdot \mathrm{HCl}) \mathbf{4}$ was prepared. The melt point is $170-171^{\circ} \mathrm{C}$ (lit. ${ }^{5} \mathrm{mp} 169-170^{\circ} \mathrm{C}$ ).

trans-4-Hydroxy-N-benzyloxycarbonyl-L-proline Meth$y l$ Ester $(\mathrm{N}-\mathrm{Z}-\mathrm{Hpr}-\mathrm{OMe}) \mathbf{5}$. $\mathrm{Hpr}-\mathrm{OMe} \cdot \mathrm{HCl} 4(5.45 \mathrm{~g}$, $30 \mathrm{mmol})$ was dissolved in water $(38 \mathrm{ml})$ and the solution was placed in a flask; ethyl acetate $(94 \mathrm{ml})$ was added, and the mixture was cooled to $5^{\circ} \mathrm{C}$. With stirring, $\mathrm{NaHCO}_{3}(7.56 \mathrm{~g})$ and a $50 \%$ solution of benzylchloroformate in toluene $(9.44 \mathrm{ml})$ were added to the flask. Stirring was continued for $30 \mathrm{~min}$. The aqueous phase was discarded. The organic phase was washed with $0.1 \mathrm{~N}$ $\mathrm{HCl}(38 \mathrm{ml})$ and a saturated $\mathrm{NaCl}$ solution $(38 \mathrm{ml})$, dried over $\mathrm{Na}_{2} \mathrm{SO}_{4}$, then evaporated to dryness under reduced pressure. Colorless oil 5 was given, yield 97\%. IR (neat) $3420,3010,2950,1740,1700,1420,1200,765$, $700 \mathrm{~cm}^{-1} ;{ }^{1} \mathrm{H} \mathrm{NMR}\left(\mathrm{CDCl}_{3}\right) \delta 7.31-7.24(\mathrm{~m}, 5), 5.15$ $(\mathrm{d}, 0.5, J=12.4 \mathrm{~Hz}), 5.09(\mathrm{dd}, 1, J=12.4,17.5 \mathrm{~Hz}), 4.95$ (d, $0.5, J=12.4 \mathrm{~Hz}), 4.46(\mathrm{q}, 1, J=8.1 \mathrm{~Hz}), 4.40$ (br s, 1), 3.70 and $3.50(\mathrm{~s}, 3), 3.64-3.52(\mathrm{~m}, 2), 3.21-3.05(\mathrm{bd}$, 1), 2.29-2.21 (m, 1), 2.04-1.99 (m, 1) ppm; MS m/z (relative intensity) $279\left(\mathrm{M}^{+}, 9\right), 220(74), 176(76), 91$ (100); Anal. Calcd for $\mathrm{C}_{14} \mathrm{H}_{17} \mathrm{NO}_{5}: \mathrm{C}, 60.21 \%$; $\mathrm{H}$, $6.14 \%$; N, 5.02\%. Found: C, 59.96\%; H, 6.28\%; N, $4.77 \%$.

\section{Synthesis of Polymer}

In general, the polymerization was conducted in a round flask with a sidearm. The flask was charged with a purified monomer 2 or $5(8 \mathrm{mmol})$ and a catalyst stannous octoate $(80 \mathrm{mg})$. The reaction was carried out under vacuum $(20 \mathrm{mmHg})$ at $140^{\circ} \mathrm{C}$ for $16-24 \mathrm{~h}$. The crude polymer was dissolved in tetrahydrofuran and then precipitated into $n$-hexane with stirring. After purification, white fine powder polymer was obtained.

Poly(trans-4-hydroxy-N-benzyloxycarbonyl-L-proline) $[\operatorname{poly}(\mathrm{N}-\mathrm{Z}-\mathrm{Hpr}-\mathrm{OH})] \mathrm{3}$. The yield of poly(trans-4-hydroxy- $N$-benzyloxycarbonyl-L-proline) [poly $(N-Z-H p r-$ $\mathrm{OH})] 3$ was $53 \%$; mp $135-138^{\circ} \mathrm{C}$; GPC $M_{w}=254000$, $M_{n}=32000, M_{w} / M_{n}=7.9 ;{ }^{1} \mathrm{H}$ NMR $\left(\mathrm{CDCl}_{3}\right) \delta 7.33-$ 7.27 (m, 5), 5.34 (br s, 1), 5.12-5.06 (m, 2), 4.39-4.31 (m, 1), 3.79 (s, 1), 3.57 (br s, 1), 2.35 (br s, 1), 2.01 (br s, 1) ppm; IR (KBr) 3430, 3010, 2950, 1760-1650, 1420, 1350, 1180, 765, 695 $\mathrm{cm}^{-1}$; Anal. Calcd for $\mathrm{C}_{13} \mathrm{H}_{13} \mathrm{NO}_{4}$ : C, $63.15 \%$; H, 5.30\% ; N 5.66\%. Found: C, 61.22\%; H, $5.49 \% ; \mathrm{N}, 5.23 \%$.

Poly(trans-4-hydroxy- $N$-benzyloxycarbonyl-L-proline methyl ester) [poly $(\mathrm{N}-\mathrm{Z}-\mathrm{Hpr}-\mathrm{OMe})] \mathrm{6}$. The yield of poly(trans-4-hydroxy- $N$-benzyloxycarbonyl-L-proline methyl ester) $[\operatorname{poly}(N-\mathrm{Z}-\mathrm{Hpr}-\mathrm{OMe})] 6$ was $66 \%$; mp $85-88^{\circ} \mathrm{C}$; GPC $M_{w}=33000, M_{n}=32000, M_{w} / M_{n}=1.03$; ${ }^{1} \mathrm{H} \mathrm{NMR}\left(\mathrm{CDCl}_{3}\right) \delta 7.31-7.26(\mathrm{~m}, 5), 5.34$ and 4.91 (br s, 1), 5.12-5.01 (m, 2), 4.40-4.37 (m, 1), 3.76 (s, 1), 3.56 (br s, 1), 2.35 (br s, 1), 2.01 (br s, 1) ppm; IR (KBr) 4330, 3010, 2950, 1760-1660, 1415, 1350, 1180, $765,698 \mathrm{~cm}^{-1}$. Anal. Calcd for $\mathrm{C}_{13} \mathrm{H}_{13} \mathrm{NO}_{4}$ : C, $63.15 \%$; H, 5.30\%; N, 5.66\%. Found: C, 62.16\%; H, 5.51\%; N, $5.24 \%$.

Deprotection of Poly(trans-4-hydroxy- $N$-benzyloxycarbonyl-L-proline methyl ester) 6. Palladium catalyst $(4 \mathrm{~g})$ was added to a solution of polymer $6(1.2 \mathrm{~g})$ in $N, N$-dimethylformamide (DMF) $(16 \mathrm{ml})$. With vigorous stirring, $98 \%$ formic acid $(56 \mathrm{ml})$ was slowly added to the mixture. At beginning the evolution of hydrogen was vigorous and ceased after $c a$. $1 \mathrm{~h}$. Stirring was continued at room temperature for $14 \mathrm{~h}$ and then the palladium catalyst was removed by filtration and washed with $1 \mathrm{~N}$ $\mathrm{HCl}(80 \mathrm{ml})$. The washing was combined with the filtrate. The combined solution was concentrated to a total volume of $20 \mathrm{ml}$ by partial evaporation under reduced pressure. The concentrated solution was then mixed with $1 N \mathrm{HCl}$ $(40 \mathrm{ml})$ to complete replacement of the formate salt by hydrochloride acid. Finally, the acidic polymer solution was poured into acetone to precipitate polymer as colorless powder (polymer 7): yield $345 \mathrm{mg} .{ }^{1} \mathrm{H}$ NMR $\left(\mathrm{D}_{2} \mathrm{O}\right)$, see Figure 1C, IR (neat), see Figure $2 \mathrm{C}$. 
$\mathrm{N}-\mathrm{Z}-\mathrm{Hpr}-\mathrm{OMe} 5$ (A)
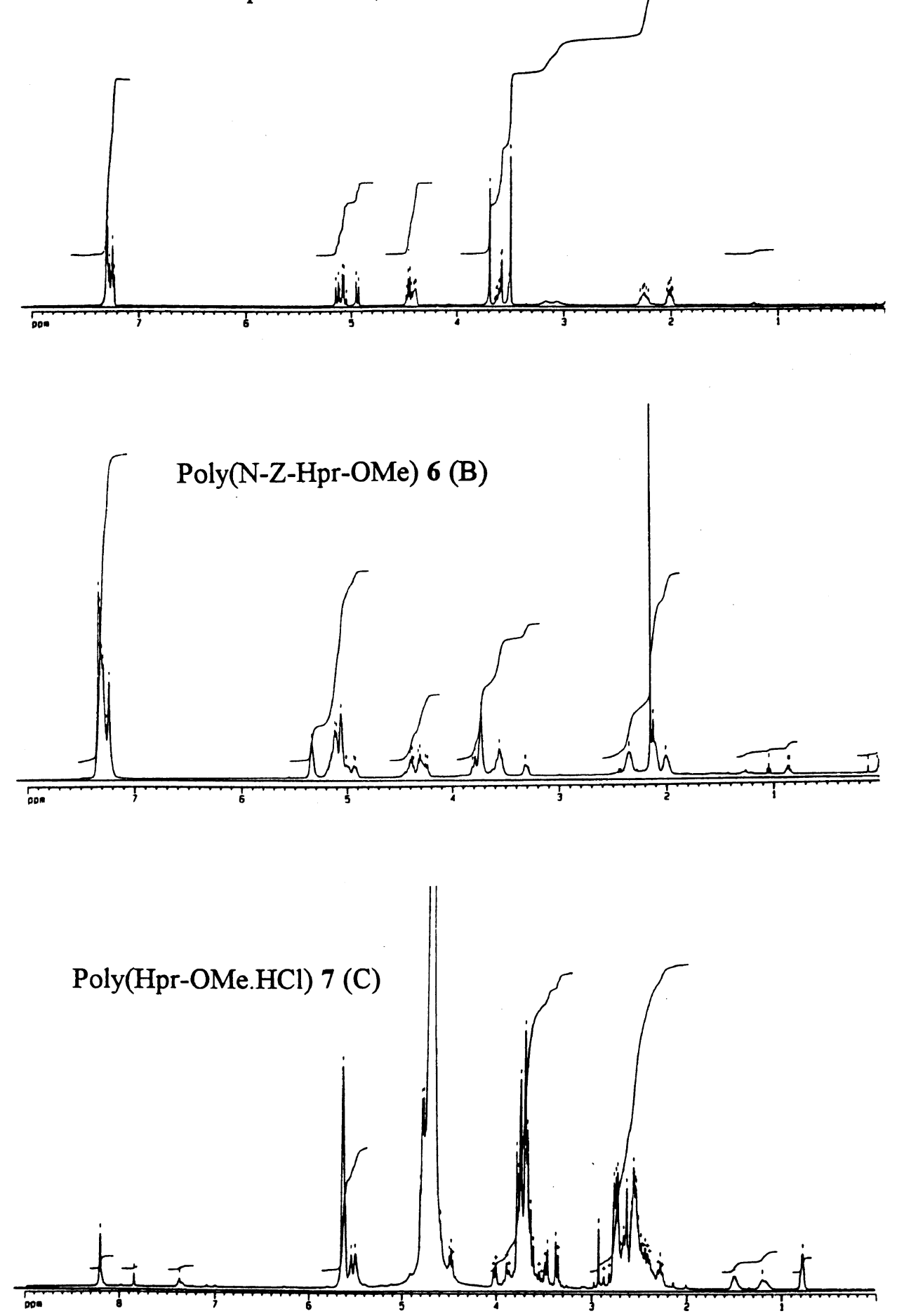

Figure 1. Representative ${ }^{1} \mathrm{H}$ NMR spectra. (A) ${ }^{1} \mathrm{H}$ NMR spectrum of $N-Z$-Hpr-OMe $5^{9}$ in $\mathrm{CDCl}_{3}$. The major peaks assignment $(\delta)$ : $7.31-7.24$ $(\mathrm{m}, 5 \mathrm{H}, \mathrm{Ph}), 5.15$ and $4.95\left(\mathrm{~d}, 1 \mathrm{H}, \mathrm{C}_{4}-\mathrm{H}\right), 5.09\left(\mathrm{dd}, 1 \mathrm{H}, \mathrm{C}_{5}-\mathrm{H}\right), 4.46\left(\mathrm{q}, 1 \mathrm{H}, \mathrm{C}_{5}-\mathrm{H}\right), 4.40\left(\mathrm{br} \mathrm{s}, 1 \mathrm{H}, \mathrm{C}_{2}-\mathrm{H}\right), 3.70$ and $3.50(\mathrm{~s}, 3 \mathrm{H}$, methyl ester), $3.64-3.52\left(\mathrm{~m}, 2 \mathrm{H},-\mathrm{CH}_{2} \mathrm{Ar}\right), 3.21-3.05(\mathrm{br} \mathrm{d}, 1 \mathrm{H}, \mathrm{OH}), 2.29-2.21$ and $2.04-1.99\left(\mathrm{~m}, 2 \mathrm{H}, \mathrm{C}_{3}-\mathrm{H}\right)$. (B) ${ }^{1} \mathrm{H}$ NMR spectrum of poly $(N-Z-\mathrm{Hpr}-\mathrm{OMe})$ 6 in $\mathrm{CDCl}_{3}$. The major peaks assignments $(\delta): 7.31-7.26(\mathrm{~m}, 5 \mathrm{H}, \mathrm{Ph}), 5.34$ and $4.91\left(\mathrm{br} \mathrm{s}, 1 \mathrm{H}, \mathrm{C}_{4}-\mathrm{H}\right), 5.12-5.01\left(\mathrm{~m}, 2 \mathrm{H}, \mathrm{C}_{5}-\mathrm{H}\right), 4.40-4.37(\mathrm{~m}$, $1 \mathrm{H}, \mathrm{C}_{2}-\mathrm{H}$ ), 3.76 and 3.56 (br s, $\left.2 \mathrm{H},-\mathrm{CH}_{2}-\mathrm{Ar}\right), 2.35$ and $2.01\left(\mathrm{br} \mathrm{s}, 2 \mathrm{H}, \mathrm{C}_{3}-\mathrm{H}\right)$. Residual acetone in the tube, gave rise to the peak at $2.1 \mathrm{ppm}$. (C) ${ }^{1} \mathrm{H}$ NMR spectrum of poly $(\mathrm{Hpr}-\mathrm{OMe} \cdot \mathrm{HCl}) 7$ in $\mathrm{D}_{2} \mathrm{O}$. The major peaks assignment $(\delta): 5.65\left(\mathrm{~s}, 1 \mathrm{H}, \mathrm{C}_{4}-\mathrm{H}\right), 3.75-3.62\left(\mathrm{~m}, 2 \mathrm{H}, \mathrm{C}_{5}-\mathrm{H}\right)$, $2.94-2.46\left(\mathrm{~m}, 2 \mathrm{H}, \mathrm{C}_{3}-\mathrm{H}\right)$. The resonance of $\mathrm{C}_{2}$ proton and possibly also the resonance of the amino protons were partially overlapped by the strong water absorptions at $4.6 \mathrm{ppm}$.

\section{RESULTS AND DISCUSSION}

Our approach to the design of such polymerization reactions is based on the use of trifunctional amino acids as monomeric starting materials. The hydroxyproline was chosen as a model monomer because of the structural simplicity and it is a major constituent of collagen. ${ }^{6}$ After protection of the $\mathrm{N}$ terminus, the pseudopolymer was obtained by the polymerization via the side chain hydroxyl group and the $\mathrm{C}$ terminus. 


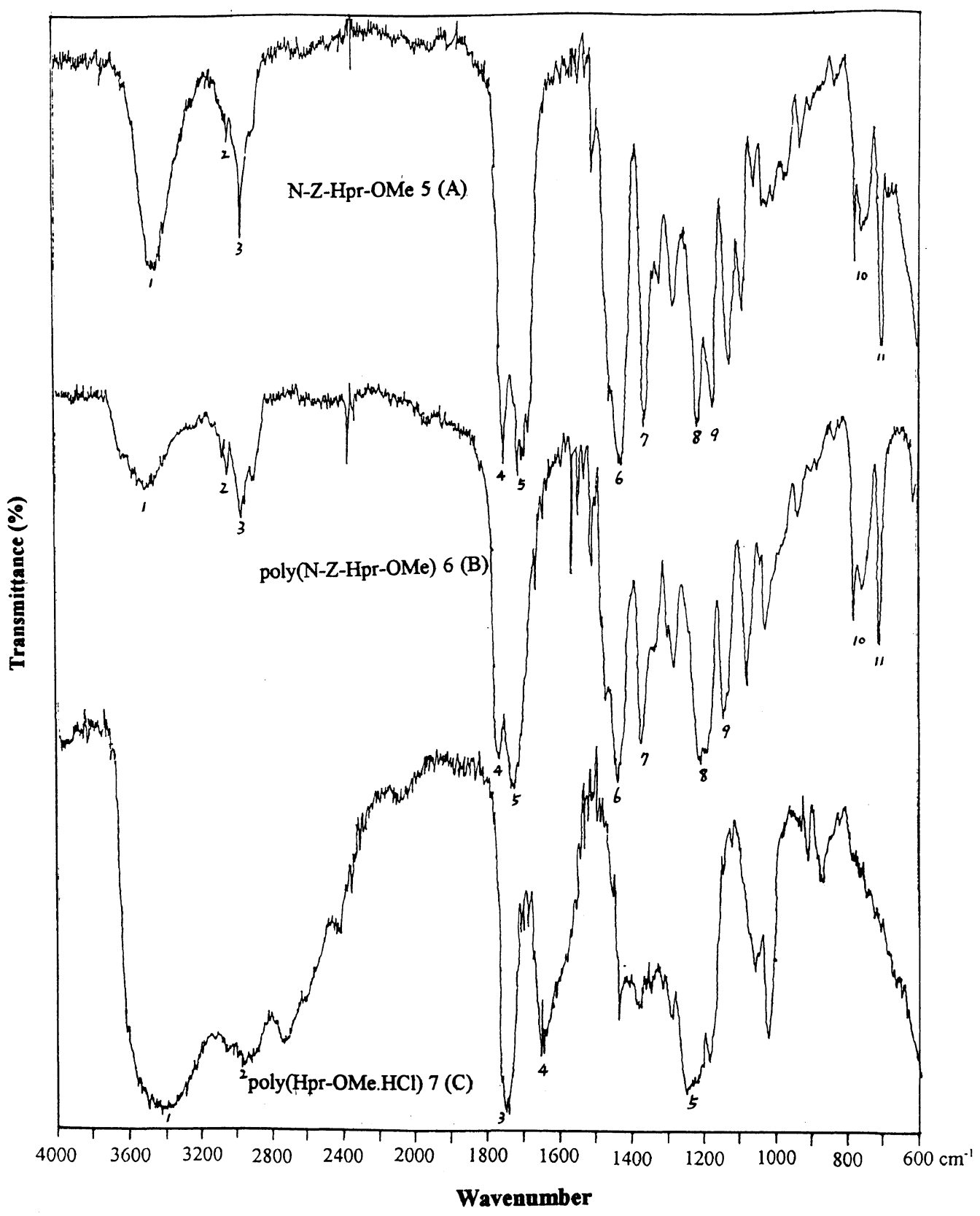

Figure 2. Representative IR spectra. (A) IR spectrum ( $\mathrm{KBr}$, pellet) of $N$-Z-Hpr-OMe 5. Peak assignment $\left(v, \mathrm{~cm}^{-1}\right.$ ): peak 1, 3420 (br, OH); peak 2, 3010 (arom. CH); peak 3, $2950(\mathrm{CH})$; peak 4, 1740 (ester carbonyl); peak 5, 1700 (urethane carbonyl); peak 6, 1420 (CN of urethane); peak 7, 8 , and 9, 1390, 1250, and 1195 (CO for ester and urethane); peak 10 and 11, 765, 700 (monosubstituted benzene). (B) IR spectrum (KBr, pellet) of poly $\left(N\right.$-Z-Hpr-OMe) 6. Peak assignment $\left(v, \mathrm{~cm}^{-1}\right)$ : peak 1, $3430(\mathrm{br}, \mathrm{NH}, \mathrm{OH})$; peak 2, 3010 (arom. $\left.\mathrm{CH}\right)$; peak 3, $2950(\mathrm{CH})$; peak 4, 1760 (ester carbonyl); peak 5, 1720 (urethane carbonyl); peak 6,1450 (CN of urethane); peak 7, 8, and 9, 1380, 1200, and 1150 (CO for ester and urethane); peak 10 and 11, 765, 698 (monosubstituted benzene). (C) IR spectrum (neat) of poly $(\mathrm{Hpr}-\mathrm{OMe} \cdot \mathrm{HCl}) 7 . \mathrm{Peak}$ assignment $\left(v, \mathrm{~cm}^{-1}\right.$ ): peak 1, 3400; peak 2, 2950 (ammonium band); peak 3, 1750 (ester carbonyl); peak 4, $1650\left(\mathrm{NH}_{3}{ }^{+}\right)$; peak 5, $1250(\mathrm{CO})$.

In order to find a generally applicable synthetic route for the preparation of pseudopoly(amino acid), two different approaches, the melt transesterification of $N$ protected 4-hydroxy-proline methyl ester and melt esterification of $\mathrm{N}$-protected 4-hydroxy-proline, were investigated.

\section{Melt Transesterification}

The transesterification of $N$-benzyloxycarbonyl-trans4-hydroxy-L-proline methyl ester $(N-Z$-Hpr-OMe) 5 was investigated. The advantage of transesterification is that it can be catalyzed by a variety of catalysts such as bases, Lewis acids, and numerous coordination compounds.
The polymerization of $N$-Z-Hpr-OMe 5 was investigated in the presence of several known transesterification catalysts, including aluminum isopropoxide, titanium isopropoxide and stannous octoate at $140^{\circ} \mathrm{C}$ under vacuum $(20 \mathrm{mmHg})$ for $16 \mathrm{~h}$.

Some transesterification occurred in the reaction mixutre. The evolution of bubble of methanol was observed and the viscosity of reaction mixture increased. From the analysis of the reaction product, the most promising result was found with stannous octoate as a catalyst. The result of the absorption peak of $\mathrm{C}_{4}-\mathrm{H}$ shifting to $5.34 \mathrm{ppm}$ in the ${ }^{1} \mathrm{H}$ NMR spectrum clearly indicated the presence of the polymer (Figure 1B). The 
Table I Molecular weight, thermal properties of poly $(N-Z$-Hpr-OH) 3 and poly $(N-Z$-Hpr-OMe $) 6$

\begin{tabular}{lrccc}
\hline \multicolumn{1}{c}{ Polymer } & \multicolumn{1}{c}{$M_{w}{ }^{\mathrm{b}}$} & \multicolumn{1}{c}{$M_{n}$} & $T_{\mathrm{g}} /{ }^{\circ} \mathrm{C}^{\mathrm{c}}$ & $T_{\max } /{ }^{\circ} \mathrm{C}^{\mathrm{d}}$ \\
\hline Poly $(N-Z$-Hpr-OMe $)$ & 33000 & 32000 & 70 & 340 \\
Poly $(N-Z$-Hpr-OH $)$ & 254000 & 32000 & 78 & 342 \\
\hline
\end{tabular}

${ }^{\text {a }} \mathrm{N}$-Z-hydoxyproline monomers were melt polymerized at $140^{\circ} \mathrm{C}$ with stannous octoate under vacuum $(20 \mathrm{mmHg})$ for $16-24 \mathrm{~h}$. ${ }^{\mathrm{b}}$ Molecular weight was determined by GPC relative to polystyrene standards in tetrahydrofuran. ${ }^{\mathrm{c}}$ The DSC analysis was conducted from -80 to $250^{\circ} \mathrm{C}$ at a heating rate of $20^{\circ} \mathrm{C} \mathrm{min}^{-1}$. ${ }^{\mathrm{d}}$ The temperature of maximum decomposition when the analysis was conducted from 25 to $550^{\circ} \mathrm{C}$ at a heating rate of $10^{\circ} \mathrm{C} \mathrm{min}^{-1}$.

weight-average molecular weight $\left(M_{w}\right)$ of this product [poly $(N-Z-H p r-O M e)] 6$ is 33000 by GPC (Table I).

\section{Melt Esterification}

The esterificaton of $N$-benzyloxycarbonyl trans-4hydroxy-L-proline $(N-Z-H p r-O H) 2$ was also investigated under the same conditions. $M_{w}$ of this product $[\operatorname{poly}(N-Z-H p r-O H)] 3$ is 254000.

In the condensation reaction, the carboxylic acid derivatives are more reactive than carboxylic ester, and the reaction rate of the esterification is faster than the transesterification. Therefore, the $M_{w}$ of $[\operatorname{poly}(N-Z-H p r-$ $\mathrm{OH})] 3$ is higher than $[\operatorname{poly}(N-Z-\mathrm{Hpr}-\mathrm{OMe})] 6$.

\section{Thermal Properties}

The glass transition temperatures $\left(T_{\mathrm{g}} \mathrm{s}\right)$ of poly $(N-Z$ $\mathrm{Hpr}-\mathrm{OH}) 3$ and poly $(N-Z$-Hpr-OMe $) 6$ were determined by differential scanning calorimetry. All of the samples were heated to $250^{\circ} \mathrm{C}$ and then cooled to $-80^{\circ} \mathrm{C}$. $T_{\mathrm{g}}$ appeared at 78 and $70^{\circ} \mathrm{C}$, respectively (Table I). The results agreed with the reported values of Langer et al. ${ }^{4 \mathrm{~b}}$ According to the DSC analysis, these homopolymers were completely amorphous.

TGA analysis of poly $(N-Z-H p r-O H) 3$ and poly $(N-Z$ $\mathrm{Hpr}-\mathrm{OMe}) 6$ were carried out in the temperature range of 25 to $550^{\circ} \mathrm{C}$ under nitrogen. It was found that the two polymers had similar initial decomposition temperatures $\left(T_{\mathrm{d}} \mathrm{s}\right)$. The temperatures of maximum rate of weight loss $\left(T_{\max }\right)$ are 342 and $340^{\circ} \mathrm{C}$, respectively (Table I).

$T_{\mathrm{g}}$ and $T_{\max }$ of $\operatorname{poly}(N-\mathrm{Z}-\mathrm{Hpr}-\mathrm{OH}) 3$ were higher than those of poly $(N-Z$-Hpr-OMe $) 6$. This might be due to the fact that poly $(N-Z-H p r-O H) 3$ has stronger hydrogen bond and higher molecular weight.

Synthesis of Poly(trans-4-hydroxy-L-proline ester) 7 by Removal of the Amino Protecting Group

The benzyloxycarbonyl group is usually removed either by acidolysis ( $\mathrm{HBr} / \mathrm{HOAc})$ or by catalytic hydrogenation. ${ }^{8}$ In order to avoid the possible degradation of the polyester backbone, treatment with catalytic hydrogenation might be better than the treatment with strong acid. So the procedure by Kohn et al. ${ }^{3 \mathrm{~b}}$ was used in this experiment. From the results of ${ }^{1} \mathrm{H}$ NMR $\left(\mathrm{D}_{2} \mathrm{O}\right)$ and IR (neat) spectra, poly(trans-4-hydroxy-L-proline ester) 7 was in agreement with the as- signed structure. The absorption bands at 1750 and $1260-1200 \mathrm{~cm}^{-1}$ can be assigned to the ester carbonyl and $\mathrm{C}-\mathrm{O}$ groups of poly (trans-4-hydroxy-L-proline ester) 7 , respectively. The typical peak of the $\mathrm{R}-\mathrm{NH}_{3}{ }^{+}$group is at $1650 \mathrm{~cm}^{-1}$. By the disappearance of aromatic proton resonances of the benzyloxycarbonyl group at $c a .7 .3 \mathrm{ppm}$ (Figure $1 \mathrm{C}$ ) and the absence of the aromatic $\mathrm{C}-\mathrm{H}$ outof-plane bending absorptions at 765 and $698 \mathrm{~cm}^{-1}$ (Figure 2C), the removal of the benzyloxycarbonyl group was confirmed.

\section{CONCLUSIONS}

$N$-Protected poly(trans-4-hydroxy-L-proline) $[\operatorname{poly}(N$ $Z$-Hpr-OH)] 3 and poly(trans-4-hydroxy-L-proline ester) [poly $(N-Z-H$ pr-OMe $)]$ 6, with $M_{w}$ of $c a .254000$ and 33000 , respectively, can be prepared by melt esterification (or transesterification) of the corresponding $N$-protected trans-4-hydroxy-L-proline. Poly $(N-Z-H p r-O H) 3$ has higher $T_{\mathrm{g}}$ and thermal stability.

After removal of the benzyloxycarbonyl protecting group by catalytic transfer hydrogenation, poly (trans-4hydroxy-L-proline ester $\cdot \mathrm{HCl})[\operatorname{poly}(\mathrm{Hpr}-\mathrm{OMe} \cdot \mathrm{HCl})] 7$ was obtained. Poly $(\mathrm{Hpr}-\mathrm{OMe} \cdot \mathrm{HCl}) 7$ is a new, chiral polymer that carries one pendent amino group per repeating unit. The feature among available polymers should facilitate the attachment of cross-linkers, drugmolecules, or various other pendent groups to the polymer backbone. We therefore expect that poly(Hpr-OMe. $\mathrm{HCl} 7$ may find applications as a degradable biomaterial.

Acknowledgments. We thank for the support by grants from the National Science Council, and Chang Gung University.

\section{REFERENCES}

1. W. S. Shalaby, "Biomedical Polymer Designed to Degrade Systems," Academic Press, New Jersey, 1994, Chapter 5.

2. M. Chasin and R. Langer, "Biodegradable Polymers as Drug Delivery System," Academic Press, New Jersey, 1990, Chapter 6.

3. (a) M. E. Gelbin and J. Kohn, J. Am. Chem. Soc., 114, 3962 (1992). (b) Q. X. Zhon and J. Kohn, Macromolecules, 23, 3399 (1990).

4. (a) J. Kohn and R. Langer, J. Am. Chem. Soc., 109, 817 (1987). (b) H. Y. Kwon and R. Langer, Macromolecules, 22, 3250 (1989).

5. J. P. Greenstein and M. Winitz, "Chemistry of the Amino Acids," Vol. 2, John Wiley, New York, N.Y., 1961, procedure 10-50, p 927.

6. (a) A. B. Mauger, "Chemistry and Biochemistry of Amino Acids, Peptides, and Proteins,' Vol. 4, B. Weinstein, Ed, Marcel Dekker, New York, N.Y., 1977, pp 179-240.

(b) J. P. Greenstein and M. Winitz, "Chemistry of the Amino Acids," Vol. 3, John Wiley, New York, N.Y., 1961, pp $2018-2042$.

7. S. R. Sandler and W. Karo, "Polymer Synthesis," Vol. 1, Academic Press, New York, N.Y., 1974, p 62.

8. M. Bodanszky, "Principles of Peptide Synthesis," SpringerVerlag: New York, N.Y., 1984, p 98.

9. The analytical spectral data of $N-Z$-Hpr-OMe 5 was identical to the result described by S. C. Mayer, J. Ramanjulu, M. D. Vera, A. J. Pfizenmayer, and M. M. Joullie, J. Org. Chem., 59, 5192 (1994). 